\title{
Loyalty towards Online Food Delivery Service: The Role of E-Service Quality and Food Quality
}

\begin{abstract}
This study assesses the direct influence of food quality and e-service quality on customer loyalty towards OFD service and its indirect influence through the mediation of customer satisfaction and perceived value. This study uses a survey of 405 OFD service customers from Bandung, Indonesia. By applying variance-based partial least squares to evaluate the proposed model, this study confirms the direct effect of food quality on online loyalty, but not e-service quality. Further, this study discloses the partial mediation role of customer satisfaction and perceived value on the relationship between both food quality and e-service quality on online loyalty towards OFD services.
\end{abstract}

Keywords: E-service quality, food quality, loyalty, online food delivery service

\section{Introduction}

The progress in internet technology which facilitates the e-commerce activities has altered the behaviour of both consumers and firms. The availability of e-commerce platforms as a shopping medium enables customers to shop conveniently, compare products and prices effectively, and arrange the delivery of the product immediately (Chang, Chou, \& Lo, 2014; Yeo, Goh, \& Rezaei, 2017). In the restaurant context, the availability of online technology enables customer to order the food through restaurant websites or via online food delivery services such as Eat24, GrabFood, and GoFood. For the restaurant industry, the availability of online delivery service technology enables the industry, which is in a saturated market, to improve order accuracy, increase productivity, and enhance customer relationship (Kimes, 2011), and extend their market (Ng, Wong, \& Chong, 2017; Yeo et al., 2017). Among online shopping, recent development shows that food has become one of the most preferred shopping and is growing rapidly, $12 \%$ per year (Chang et al., 2014).This development is an opportunity as well as a challenge for restaurants, as it creates a fierce competition. In this challenging environment, having loyal customers is imperative for online business firms (Pee, Jiang, \& Klein, 2018).

The importance of customer loyalty, as well as its determinants, is well discussed in the literature. Among the loyalty drivers, literature tends to agree that quality of product or services, perceived value, and customer satisfaction are building blocks of loyalty (Wirtz \& Lovelock, 2016). However, although a plethora of researches on loyalty have been conducted in various industries, scholars (Abou-Shouk \& Khalifa, 2017; Caruana \& Ewing, 2010) believe that the formation of customer loyalty is still not thoroughly understood. In addition, the result of studies in one industry will be difficult to generalize to other industries due to characteristic differences; thus, scholars recommend examining loyalty formation in other new industry sectors (Gursoy, Chen, \& Chi, 2014). Although the OFD service business is currently flourishing and promising in the future (Kedah, Ismail, Haque, \& Ahmed, 2015; Yeo et al., 2017), surprisingly, literature seems to be silent in understanding what drives customer loyalty towards OFD services.

Studies in the restaurant context (Kedah et al., 2015; Yeo et al., 2017) reported that the customer experience is substantially affected by food quality and e-service quality. Despite the importance of both qualities, literature seems to be relatively absent in addressing the 
simultaneous effect of those qualities on customer online loyalty, especially in the OFD services environment. Driven by this research gap, this study examines how e-service quality as well as food quality impacts on loyalty towards OFD services. More specifically, this study proposes to evaluate (1) the direct influence of e-service quality and food quality on online loyalty and (2) the indirect influence through perceived value and customer satisfaction mediation role. Conducting such a study will provide an avenue for restaurateurs to develop more effective strategies to target their market and will extend the existing consumer loyalty knowledge from the perspective of the OFD services.

A report (Statista, 2018) shows that even with a penetration of only $50.4 \%$, the absolute number of Indonesians using these services is enormous, given that there are 132.7 million internet users in Indonesia. Further, the report reveals that the Indonesian segment for food delivery market is paramount as the value of transactions is US\$ 968 Million in 2018 and is expected to grow at $13 \%$ per annum. The players of the OFD business in Indonesia are not only international fast-food restaurants such as McDonald's and Kentucky Fried Chicken, which operate their own delivery services but also many small and medium casual dining and fastfood restaurants which use food delivery service intermediaries such GoFood and GrabFood. This indication clearly shows an intense competition in the Indonesian OFD service industry. Therefore, by the value of the market alone, it is reasonable to study online loyalty towards OFD services in the Indonesian market.

\section{Theoretical framework and hypotheses development}

\subsection{Online Loyalty}

In a competitive and challenging business environment, such as in the restaurant industry, having customer satisfaction on its own is not enough to ensure business survival, let alone to increase business success (Ha \& Jang, 2010). The key for survival and flourishing in this competitive environment is through having loyal clients. Loyalty is "a deeply held commitment to repurchase or re-patronize a preferred product or service consistently in the future despite situational influences and marketing efforts" (Oliver, 1999, p. 34). Loyalty towards a product or service comprises of brand loyalty, vendor loyalty, service loyalty, and retail loyalty. Online loyalty or e-loyalty widens conventional loyalty by involving online technology as the mediation of the relationship between customers and the firm. Scholars (Abou-Shouk \& Khalifa, 2017; Kim, Jin, \& Swinney, 2009; Pee et al., 2018) commonly describe online loyalty as the customers' loyalty towards the website, indicating with customer intention to re-visit the website and to make a transaction and to recommend the website to others. This study focuses on online food delivery service. Thus online loyalty towards OFDs is described as the commitment of the customers towards the online food delivery service that results in repurchase and customer positive behaviours toward the OFD service providers.

Literature suggests that loyal customers increase the firm' profit through their enduring commitment towards the firm and enable the firm to lower costs in recruiting new clients (Reichheld, Markey, \& Hopton, 2000). Further studies (Kim et al., 2009; Suhartanto, Chen, Mohi, \& Sosianika, 2018) reveal that loyal customers tend to purchase more than newly acquired customers, pay premium prices, refer new customers to the firm, and lessen operating costs. Thus, having online loyal customers can accelerate profit growth although the expenditure of developing online loyalty is bigger than that of traditional loyalty (Kim et al., 2009). Fandos and Flavián (2006) suggest that to convert a first time customer to a loyal customer, managers need to identify customer expectations and provide a unique product and service that exceed their customers' expectations. Thus, the need for food purchased through OFD services is based on a combination of online processing, food preparation, and prompt 
delivery service (Kedah et al., 2015; Yeo et al., 2017) and requires that the food and its services are well designed and exceeds the customer's expectation.

Three approaches are used to evaluate customer loyalty towards a product or service. Firstly, loyalty is conceptualized as behaviour. Using this behavioural approach, a loyal consumer is one who systematically purchases the product or services within a certain period (Suhartanto, Chen, et al., 2018). In the OFD setting, a loyal customer according to this approach is one who orders the food regularly, either directly through the restaurant website or through restaurant intermediate websites. Secondly, loyalty is conceptualized as an emotional expression of customer intention to repurchase and recommend (Gursoy et al., 2014). Due to the behavioural and attitudinal weaknesses, experts (Gursoy et al., 2014) recommend a third approach, a combination of the behavioural and psychological, known as composite loyalty. The composite approach suggests that customer's loyalty towards OFD services is measured by their online purchasing and tendency to re-purchase and to recommend the OFD firm to others. This approach enables the researcher to understand not only current customer loyalty behaviour but also future customer loyalty behaviour. Thus, this study treats customer loyalty towards OFD services as composite loyalty.

\subsection{E-service quality}

The most commonly cited definition of e-service quality is "the extent to which a website facilitates efficient and effective shopping, purchasing, and delivery of products and services" proposed by Zeithaml and colleagues (2002, p. 363). The Zeithaml and colleagues description denotes that e-services quality is the customers' inclusive assessment of the electronic services offerings. Customers expect quality service of websites when making online purchases (Caruana \& Ewing, 2010). Thus, the quality of websites is crucial for the firms to market their products and services. This is particularly important in online business such as OFD services, where the interaction between the firms and their customers is only through online devices. Jeon and Jeong (2017) suggests that upholding the website quality is imperative to retain customers, persuade them to revisit the web, and finally to secure their loyalty. Consequently, keeping a high quality website is essential for the success of online businesses (Parasuraman, Zeithaml, \& Malhotra, 2005; Pee et al., 2018).

For online businesses, an innovative and well-developed website is equal to an excellent distribution channel in conventional business. Studies on e-service quality mainly focus on two issues, the dimensionality and its antecedents and consequences. An important study on eservice quality dimensionality was conducted by Parasuraman and colleagues (2005) resulting in an e-service quality measurement scale called the ES-QUAL, consisting of four dimensions: system availability, efficiency, privacy, and fulfilment. Subsequently, researchers (Bressolles, Durrieu, \& Senecal, 2014; Chang, Wang, \& Yang, 2009; Mihajlović, 2017) offer additional dimensionality models consisting of varied dimensions. In terms of the e-service quality consequences, studies have progressively taken into account the link between customer interaction with the website and their subsequent behaviours. Most previous studies suggest that customer e-loyalty is determined by customer experience with the e-service quality (Chang et al., 2014; Jeon \& Jeong, 2017; Kedah et al., 2015; Mihajlović, 2017; Pee et al., 2018). Thus, in the OFD context, the following hypothesis is formulated.

\section{$\mathrm{H}_{1}$ : E-service quality positively influences customer loyalty towards OFD services}

\subsection{Food quality}

The term food quality refers to an overall performance of food to fulfil customer need and is considered an important element of the customer experience with the restaurant (Ha \& Jang, 
2010; Sulek \& Hensley, 2004). Although past studies emphasize the importance of food quality, in terms of what attributes constitute food quality, past studies have no consensus as to its constituent aspects. Ha and Jang (2010) use food attributes of taste, nutrition, and variety to assess the influence of customers experience with food on their satisfaction as well as their intention to return to the restaurant. Liu et al. (2017) utilize the menu, presentation, size, and variety as indicators of the quality of restaurant food. Further, Sulek and Hensley (2004) state that appeal, safety, and dietary factor are the common characteristics customers use to determine the quality of food. Other scholars (Namkung \& Jang, 2007) propose variety of the menu, food presentation, healthiness, taste, freshness, and food temperature to evaluate food quality. Along with service quality, the quality of food is regarded as basic elements that influence customers' experience with the restaurant (Ha \& Jang, 2010; Liu et al., 2017; Namkung \& Jang, 2007).

Due to its important role, along with other variables, food quality has been empirically examined in various restaurant studies. Liu and colleagues (2017) confirm that customers' restaurant choice is mainly dictated by the food quality factor. In casual-dining restaurants, Mattila (2001) suggests that the quality of food is a major determinant of customer loyalty. Compared to service quality and restaurant environment, Sulek and Hensley (2004) report that satisfaction with the restaurant is influenced mainly by the quality of food. Another study to explore customer behaviour in the restaurant environment (Namkung \& Jang, 2007) reports the significant role of food quality in affecting satisfaction and intention to purchase and to recommend the restaurant (indicators of customer loyalty). Although it is the fundamental element for restaurants, none of the studies in the OFD context have assessed food quality as the determinant of customer post purchase behaviour. Referring to past studies, it is logical to assume that food quality will impact on customer loyalty towards the OFD services.

\section{$\mathrm{H}_{2}$ : Food quality positively influences loyalty towards OFD services}

Literature in restaurant studies have also reported the link between food quality, service quality, and e-service quality (Ha \& Jang, 2010; Kedah et al., 2015); however, none of the past studies have examined the impact of e-service quality on food quality. The Spillover theory postulates that experience within a particular life area, will leak to other areas of life (Sirgy, Efraty, Siegel, $\&$ Lee, 2001). Based on this theory, a customer's experiences in one part of their consumption process could affect his or her experience in the other parts of the consumption process. Testing in the hospitality sector, Kim et al. (2018) report the applicability of this theory in explaining the effects of employee perception on corporate social responsibility on job satisfaction and overall quality of life. Another study reports the applicability of this theory to assess the relationship between tourist behaviours in both their home and holiday environments (Sthapit \& Björk, 2017). In the OFD services industry, it is expected that the customers' experience with online service will spillover and affect their feelings towards the food purchased. The purchasing and delivering process comes first, prior to the customers' receipt and consumption of the food. Thus, it is suggested that the customer experience with the quality of e-service will affect the customer experience with the food.

$\mathrm{H}_{3}$ : E-service quality positively influences food quality

\subsection{The mediation role of perceived value}

The term perceived value is associated with a relative comparison between benefits and sacrifices associated with the product or service offering. The conceptual basis of perceived value is equity theory which postulates the proportion between the provider's outcome and the consumer's input (García-Fernández et al., 2018). Customers feel treated fairly if they feel that 
the proportion between their sacrifices and experiences with the product or services is equivalent (Chang et al., 2009). The perceive value's importance in online business is because customers can easily compare product features and prices. Caruana and Ewing (2010) maintain that the cost of searching in online market places is low, causing the online firms to have better competitive prices. This cost reduction increases the probability that the customers will compare the prices and the benefits offered by the product or services they buy. The relationship between the customers and the e-retailer is stronger if the customers perceive that they gain higher value for their scarification in both monetary terms as well as the nonmonetary aspects (Anderson \& Srinivasan, 2003). Further, research also strongly provides evidence of the influence of e-service quality on perceived value (Caruana \& Ewing, 2010; Chang et al., 2009; Jeon \& Jeong, 2017). This discussion suggests that the link between eservice quality and online loyalty is intermediated by perceived value. Thus, the following hypotheses are formulated.

$\mathrm{H}_{4}$ : The relationship between e-service quality and loyalty towards OFD service is mediated by perceived value

$\mathrm{H}_{5}$ : The relationship between food quality and loyalty towards OFD service is mediated by perceived value

\subsection{The mediation role of customer satisfaction}

Satisfaction is a subjective assessment of product performance associated with customer prior expectation (Suhartanto, Brien, Sumarjan, \& Wibisono, 2018). Oliver (1999) defines satisfaction as "the consumer senses that consumption fulfils some need, desire, goal, or so forth and that this fulfilment is pleasurable" (p. 34). When the customers perceive that the performance of the product or service is higher than their expectation, they are satisfied. The literature suggests that the product and service purchased affect customer satisfaction (Liu et al., 2017; Ryu \& Han, 2009; Suhartanto, Chen, et al., 2018). In the online context, studies suggest that e-satisfaction influences e-loyalty (Anderson \& Srinivasan, 2003; Pee et al., 2018). Satisfied customers with their food consumption may intend to repurchase the food in the future, endorse the OFD services to other potential customers, and voice positive remarks about the OFD services. In contrast, customers who are dissatisfied with their OFD services are less likely to repurchase or recommend the services to others. This discussion implies that in the OFD service industry, customer satisfaction mediates the relationship between e-service quality as well as food quality on online loyalty.

$\mathrm{H}_{6}$ : The relationship between e-service quality and loyalty towards OFD service is mediated by customer satisfaction

$\mathrm{H}_{7}$ : The relationship between food quality and loyalty to OFD service is mediated by customer satisfaction

\section{Figure 1 around here}

\section{Research Method}

\subsection{Scale measurement}


Although studies in e-service quality are abundant; none of the identified studies are set in the OFD context. Therefore, the measurement items for assessing the e-service quality variable (Table 1) is developed with reference to the existing studies.

\section{Table 1 around here}

Past studies show that the dimension of e-service quality varies; thus, it is necessary to examine the dimensionality of e-service quality as applied in this study. The dimensionality of e-service quality was assessed by using factor analysis. A factor analysis uses the extraction method of principal component resulting in two factors, covering $69 \%$ of Eigen value and the loading factor range from 0.723 to 0.838 . However, the loading values of all items are well-loaded into factor 1 and only a minor value to factor 2 . Further assessment using rotation methods results in a similar number of factors and their loadings, signifying that the e-service quality dimension is single. The factor analysis shows that KMO measurement of the adequacy of sampling value is 0.993 and Barlett's test of Spericity is significant at $p<0.05$, indicating that the results of the factor analysis test is robust. The single construct for measuring e-service quality is consistent with Harris and Goode (2004) study in the online retail sector. Further, the items used are consistent with the elements of efficiency, privacy, fulfilment, and system availability proposed in Parasuraman et al. (2005)' ES-QUAL model.

Following past studies (Ha \& Jang, 2010; Namkung \& Jang, 2007), this study treats food quality as a single dimension, consisting of variety, taste, attractiveness and healthiness as indicators. Thus, the exploratory factor analysis was not conducted to assess its dimension. Perceived value is measured with three items: reasonable price, overall convenience of website use, and cost and benefit ratio of transaction (Anderson \& Srinivasan, 2003; García-Fernández et al., 2018). Customer satisfaction was gauged with a 5-point, "dissatisfied" to "satisfied" and "terrible" to "pleased" (Suhartanto, Brien, et al., 2018). The online loyalty is measured by intention to repurchase, to recommend, to write positive comments on social media, and to switch to other online providers (Caruana \& Ewing, 2010; Srinivasan, Anderson, \& Ponnavolu, 2002). The measurement items for e-service quality, food quality, perceived value and loyalty were based on a 5-point Likert scale (1 strongly disagree to 5 strongly agree). To warrant that the questions and instructions are well comprehended, the questionnaire in Indonesian language was pre-tested on 20 OFD customers, resulting in minor adjustments to the questionnaire wordings. There was no need for translation.

\subsection{Data collection and sample}

This study focuses on consumers who had an online food delivery purchase experience as the sample. To conduct empirical research and test the proposed model (Figure 1), non-probability sampling method was applied as the population is not known and the sampling frame is not available. The purposive sampling is selected to collect the required data, as it can enable researchers to gather a population representative sample. The data was collected from OFD service customers in Bandung City during November and December 2017. The selfadministered questionnaires were distributed conveniently to customers who had purchased food through OFD services within the last two weeks before participating in the survey. Of the 439 participants, 405 questionnaires returned were complete. Thus, the requirements of using structural equation modelling were met, 10 respondents minimum for each survey instrument item (Chin, Peterson, \& Brown, 2008). Additionally, the requirement of a 322 sample for the 
level of confidence at $95 \%$ and $\pm 5 \%$ error margin was also fulfilled as recommended by Zikmund et al. (2013).

\subsection{Data analysis}

To assess the dimensionality of e-service quality, exploratory factor analysis was performed as proposed by Hair et al. (2010). The measurement model was examined by applying confirmatory factor analysis using variance-based Partial Least Squares (PLS). The PLS was also used to verify the structural model and test the proposed hypotheses. PLS enables a researcher to assess latent constructs using a small and medium sample size and non-normality distributed data (Ali, Rasoolimanesh, Sarstedt, Ringle, \& Ryu, 2018; Chin et al., 2008). Additionally, SEM-PLS is a noted technique to estimate coefficient paths in structural models (Hair, Hult, Ringle, \& Sarstedt, 2017).

\section{Results}

Table 2 indicates that the respondents are dominated by young customers (under 30 years old) and female customers. This demographic characteristics are consistent with other online food studies (Chang et al., 2014; Kedah et al., 2015; Kimes, 2011).

\section{Table 2 around here}

\subsection{Data analysis}

The data analysis was conducted into two stages. The first is intended to check the validity and reliability of the variable constructs. To assess the construct validity this study assesses factor loading, Average Variance Extracted (AVE) and Composite Reliability (CR). As shown in Table 3, all indicators of validity are satisfied the recommended cut-off value, factors loading of more than 0.6, composite reliability of more than 0.7, and AVE of more than 0.5 (Chin et al., 2008; Hair et al., 2010).

\section{Table 3 around here}

To assess the discriminant validity, Henseler et al. (2015) recommend Heterotrait-Monotrait method to judge the construct's discriminant validity with cut off value of not more than 0.9. Using this recommendation, the discriminant validity of the constructs tested is satisfied as all Heterotrait-Monotrait values are less than 0.9.These values suggest that the discriminant validity between the variable constructs is satisfied.

\subsection{Structural Model}

Following the measurement model, the second stage of the data analysis process was evaluating the structural model and testing the hypotheses developed. For these purposes, this study applies SmartPLS. The path coefficients assessment, as Chin et al. (2008) recommend, was conducted by using a bootstrapping procedure with 5000 iterations. Following Tenenhaus et al. (2005) suggestion, this study uses the Goodness of Fit (GoF) index to gauge the model fit. The GoF assessment result shows that the model tested has a value of 0.677 , suggesting that 
the fitness of the model is good. Further, to check the approximate fit indices, normal fit index (NFI) and standardized root mean square residual (SRMR) were applied. The results show that SRMR has a value of 0.067 (lower than the suggested value of 0.8 ) and NFI has a value of 0.905 (larger that the suggested level of 0.9) demonstrating the model fitness (Hair et al., 2017).

Succeeding the goodness of fit analysis, the hypothesized relationships were tested and the results are presented in Table 4 . The predictor explanatory power of the respective constructs is indicated by the corrected $R^{2}$ s. Figure 2 shows the E-service quality predicts $37.1 \%\left(R^{2}\right.$ : $0.371)$ food quality. Both E-service quality and food quality explain $51.4 \%\left(R^{2}: 0.514\right)$ of perceived value and $52.5 \%\left(R^{2}: 0.525\right)$ of satisfaction. While all loyalty predictors (e-service quality, food quality, perceived value, and satisfaction) predict $39.2 \%\left(R^{2}: 0.392\right)$ of customer loyalty. As the range of $R^{2}$ is between 0.33 and 0.67 , the model validity of this study can be classified as between moderate and substantial (Chin et al., 2008).

Besides the $R^{2}$ value, scholars (Ali et al., 2018; Chin et al., 2008) maintain that researchers should use predictive sample reuse $Q^{2}$ to identify the effectiveness of predictive relevance. $Q^{2}$ indicates how well the data can be reassembled by employing the PLS parameters and the proposed model. Based on the procedure of blindfolding, the result of data analysis shows that the predictive relevance $\left(Q^{2}\right)$ for endogenous variables are acceptable as their values are positive (Hair et al., 2017). The significant test on the relationships amongst the variables tested shows that hypothesis $\mathrm{H}_{1}$ is not supported; while hypothesis $\mathrm{H}_{2}$ and $\mathrm{H}_{3}$ are supported.

\section{Table 4 around here}

In addition to setting out the direct effect, Table 4 also shows the indirect and total effect of the variables tested. It reveals that although the direct effect of e-service quality on loyalty is not significant, its total effect is significant. This finding suggests that the e-service quality's effect on loyalty is through strengthening food quality, perceived value, and customer satisfaction. While the food quality, besides directly impact on customer loyalty, indirectly impact on loyalty through reinforcing perceived value and customer satisfaction. Further, Table 4 shows that, although the direct effect of food quality on loyalty is much higher than the effect of eservice quality, their total effect on online loyalty is only slightly different, 0.459 (e-service quality) and 0.435 (food quality). The direct relationships between the tested variables are depicted in Figure 2.

\section{Figure 2 around here}

\subsection{Mediation test}

To test the mediation role of satisfaction and perceived value $\left(\mathrm{H}_{4}\right.$ to $\left.\mathrm{H}_{7}\right)$, scholars (Baron \& Kenny, 1986; Nitzl, Roldan, \& Cepeda, 2016) recommendation was followed. A comparison between path coefficient value of two different models with and without the mediation variable (satisfaction and perceived value) was conducted. Testing the first model between e-service quality and online loyalty without the perceived value mediation results in a $\beta$ of 0.445 
(significant at $\mathrm{p}<0.01$ ). Testing the similar model but with the mediation of perceived value results a $\beta$ of 0.321 (significant at $\mathrm{p}<0.05$ ). To test significance of the mediation, the Sobel test statistics was applied resulting in a significant value $(\mathrm{p}<0.01)$. The reducing of the coefficient implies that the mediation is partial. The mediation test of perceived value on the link between food quality and online loyalty has $\beta$ value of 0.434 (without the mediation) and $\beta$ value of 0.311 (with the mediation). Testing the Sobel test results in a significant value $(\mathrm{p}<0.01)$, suggesting that the mediation role is also partial. Therefore, the support for hypothesis $\mathrm{H}_{4}$ and $\mathrm{H}_{5}$ are partial.

A similar procedure was applied to assess the hypothesis on the mediation of perceived value on the link between e-service quality and online loyalty. Testing the first relationship model between e-service quality and loyalty without the satisfaction mediation results in a $\beta$ of 0.364 (significant at $\mathrm{p}<0.01$ ). Testing the similar model but with the mediation of satisfaction results in a $\beta$ of 0.345 (significant at $\mathrm{p}<0.05$ ). To test the mediation role, the Sobel test was applied, resulting in a significant value $(\mathrm{p}<0.01)$. The reduction of the coefficient between e-service quality and online loyalty due to the existence of the mediator implies that customer satisfaction partially mediates the relationship (Nitzl et al., 2016). Checking the satisfaction mediation role on the link between food quality and online loyalty has a $\beta$ of 0.342 (without the mediation) and 0.234 (with the mediation). The Sobel test results in a significant value $(\mathrm{p}<0.01)$, suggesting that the mediation role is also partial. Therefore, $\mathrm{H}_{6}$ and $\mathrm{H}_{7}$ are partially supported.

\section{Discussion}

Despite the flourishing demand of food through online delivery services, the manner in which food quality and e-service quality influence loyalty toward OFD service has been ignored. This study represents the first effort to scrutinize the consequences of both food quality and e-service quality on customer post purchase behaviour in the OFD service environment. This study reveals several important points.

First, this study shows the importance of food quality in influencing customer loyalty towards the OFD service. Further, the result of this study suggests that the consequence of the quality of food on online loyalty is partly intermediated by both satisfaction and perceived value. The food quality influence on online loyalty is through strengthening the customer's perceived values as well as the customer level of satisfaction. This result validates Chang et al. (2014) study in online group buying which reports that food's quality affects consumers buying food via online. Further, this study corroborates with past studies in the restaurant setting, that food quality is an imperative determinant of customer loyalty (Mattila, 2001; Namkung \& Jang, 2007; Ryu \& Han, 2009). When the food is of high quality, customers tend to repurchase and recommend the food in the future. This is also reflected in their behaviour of continuously consuming the food. This finding implies that food quality is a fundamental component, not only in a conventional restaurant context but also in the context of OFD services. Therefore, it is important that the casual dining and fast-food restaurants offering OFD service provide high quality foods that not only match with customer needs but are also superior to the competitors' foods. To outperform competitors, they should concentrate on food presentation, taste, variety, and healthiness.

Second, in terms of e-service quality, this study reveals that this service is essential in determining food quality, perceived value, and satisfaction, but contrary to past studies in online retail as well as in the restaurant (Ha \& Jang, 2010; Kim et al., 2009), it has an insignificant direct effect on customer loyalty. However, looking at the total effect of e-service quality (direct effect and indirect effect through food quality, perceived value, and satisfaction) on loyalty, this factor has a considerable total effect on customer loyalty. This result implies 
that e-service quality not only strengthens food quality but also reinforces perceived value as well as customer satisfaction which subsequently create online loyalty. This finding means that high e-service quality per se does not encourage an OFD customers' loyalty. The explanation of this finding is that the food, not the service, is the main purpose of customers using OFD service. Although e-service quality is not the object that fulfils customer's need, it will impact the perception of food quality, resulting in a high perceived value and satisfaction which ultimately creates customer loyalty towards the OFD service. Because online food order is selfservice (Kimes, 2011), a well-designed self-service ordering system through online devices is crucial in creating satisfaction, perceived value, and continuing online loyalty.

Third, the total effect of both e-quality and food quality shows that the overall impact of both qualities on loyalty towards OFD services is comparable. This result suggests that, in general, food quality and E-service quality are equally important determinants of customer loyalty. This result is different from a past study (Ha \& Jang, 2010) which reports that compared to other restaurant elements such as service quality and restaurant environment, the quality of food is the dominant factor in influencing customer experience towards the restaurant. This finding suggests that in developing customer loyalty, the OFD service providers must emphasize both factors, rather than only focusing on either e-service or the food quality itself. This finding suggests that both e-service and food are not only important components in a full service restaurant (Namkung \& Jang, 2007) but also important for restaurants offering OFD services. This finding is important as none of past studies have reported this issue. From a theoretical perspective, the fitness of the OFD service model tested in this study extends the existing knowledge (Han \& Hyun, 2017; Wirtz \& Lovelock, 2016) that quality (product, service, and e-service), perceived value, and satisfaction are the building blocks of online loyalty in the OFD context.

Last, this study reveals an important finding in term of the link between e-service quality and food quality, which suggests that e-service quality influences food quality. This result is consistent with the service process. In the OFD services, although food is the fundamental element to satisfy customer need, the process of consuming the food starts from when the customers search and order food from the firm website or application. Therefore the customer experience with the web quality will influence customer perception of the food quality. This finding is consistent with the study in conventional restaurant (Namkung \& Jang, 2007; Ryu \& Han, 2009) that conclude that the manner of service delivery will influence the customer experience with the food. From conceptual perspective, this significant link between e-service quality and food quality provides a new understanding by supporting the spillover theory in the hospitality industry (Kim et al., 2018; Sthapit \& Björk, 2017), more specifically in the OFD services environment. 


\section{Managerial Implication}

First, the e-service quality element in determining customer loyalty towards OFD services provide avenue managers of casual dining and fast-food restaurants offering delivery services an impetus to improve their business performance. This study suggests that having an excellent e-service quality is essential. In the online environment, food, like other products presented through online media, are not tangible. Unlike the traditional restaurant, consumers in the OFD services cannot taste, touch, smell, and see the food offered. Rather, consumers assess the food quality by relying on the picture and the given description of the foods or services in the web page. Hence, to maximize the degree of trust of the customers, clear and understandable information should be provided in the website. Moreover, comprehensive information with reasonable explanations should be given such as the width and depth of the food and service offerings. In addition, to assist the customer to visualize the offer, demonstration of virtual food or service is also necessary to encourage customers to make the right decisions.

Next, the result of this study highlights the importance of food quality in determining customer loyalty toward OFD services. This result highlights that quality of food needs to get full attention from the managers of casual dining and fast-food restaurant offering delivery services. However, food quality indicated by its attractiveness, taste, variety, and healthiness is considered a basic element that every restaurant has to offer. To compete in this competitive market, restaurant managers must not only provide high food quality, but also need to constantly innovate their food to cope with their customers' ever changing demand. As people tend to like tradition and local flavour, offering quality innovative food with local tastes and developed based on local ingredients could help the restaurant to retain their existing customers as well as attracting potential and new customers. Thus, it is imperative for restaurant managers to train the kitchen staff to prepare delicious, nutritious, and attractively presented food with local taste and using local food ingredients.

Last, for small and medium casual dining and fast-food restaurants that do not have their own delivery service as well as the delivery service firms, this study provides useful guidance to improve their business. For the restaurateurs whose food is influenced by e-service quality, this study suggests that to improve their business, they need to select and cooperate with delivery service firms that are excellent in delivering services. Selecting the delivery service firms that have a favourable reputation will help to create a high e-service quality in the customer perception. Similarly, food delivery firms, such as GoFood and GrabFood, need to select restaurants that can provide consistently excellent food quality. The failure to have excellent food restaurant supplier will damage customer loyalty towards OFD services.

\section{Limitations and options for future research}

Although contributing significantly in extending our understanding on the determinants of loyalty toward OFD services, this study bears some drawbacks. First, data for this study was gathered from OFD customers in Bandung, Indonesia, limiting the generalization of the findings. This issue can be solved by replicating this study in different regions. Second, in addition to the loyalty determinants used in this study, identifying other elements of loyalty formation is also critically needed. To develop a robust model, a future study could incorporate other constructs such as image, trust, and involvement, including socio-demographic factors which potentially affect satisfaction and loyalty towards OFD service. Third, the OFD loyalty model tested in this study assumes the causal effect of the variables tested, in particular satisfaction and loyalty towards OFD services. The results of causal-effect test reported in this study should be taken with caution as the data is collected using cross-sectional method, 
making this study neither experimental nor longitudinal. Although the hypothesized relationships between the variables can be examined using PLS, the causal-effect relationships suggested in the model might not signify the factual causal association between the variables. The future studies could use longitudinal data to more accurately represent the relationship changes across a period of time.

\section{Reference}

Abou-Shouk, M. A., \& Khalifa, G. S. (2017). The influence of website quality dimensions on epurchasing behaviour and e-loyalty: a comparative study of Egyptian travel agents and hotels. Journal of Travel \& Tourism Marketing, 34(5), 608-623. doi: 10.1080/10548408.2016.1209151

Ali, F., Rasoolimanesh, S. M., Sarstedt, M., Ringle, C. M., \& Ryu, K. (2018). An assessment of the use of partial least squares structural equation modeling (PLS-SEM) in hospitality research. International Journal of Contemporary Hospitality Management, 30(1), 514-538. doi: doi:10.1108/IJCHM-10-2016-0568

Anderson, R. E., \& Srinivasan, S. S. (2003). E-satisfaction and e-loyalty: A contingency framework. Psychology and Marketing, 20(2), 123-138. doi: 10.1002/mar.10063

Baron, R. M., \& Kenny, D. A. (1986). The moderator-mediator variable distinction in social psychological research: Conceptual, strategic, and statistical considerations. Journal of Personality and Social Psychology, 51(6), 1173-1182. doi: 10.1037/0022-3514.51.6.1173

Bressolles, G., Durrieu, F., \& Senecal, S. (2014). A consumer typology based on e-service quality and esatisfaction. Journal of Retailing and Consumer Services, 21(6), 889-896. doi: https://doi.org/10.1016/j.jretconser.2014.07.004

Caruana, A., \& Ewing, M. T. (2010). How corporate reputation, quality, and value influence online loyalty. Journal of Business Research, 63(9), 1103-1110. doi: https://doi.org/10.1016/j.jbusres.2009.04.030

Chang, H. H., Wang, Y.-H., \& Yang, W.-Y. (2009). The impact of e-service quality, customer satisfaction and loyalty on e-marketing: Moderating effect of perceived value. Total Quality Management \& Business Excellence, 20(4), 423-443. doi: 10.1080/14783360902781923

Chang, S.-C., Chou, P.-Y., \& Lo, W.-C. (2014). Evaluation of satisfaction and repurchase intention in online food group-buying, using Taiwan as an example. British Food Journal, 116(1), 44-61. doi: 10.1108/BFJ-03-2012-0058

Chin, W. W., Peterson, R. A., \& Brown, S. P. (2008). Structural Equation Modeling in Marketing: Some Practical Reminders. Journal of Marketing Theory and Practice, 16(4), 287-298.

Fandos, C., \& Flavián, C. (2006). Intrinsic and extrinsic quality attributes, loyalty and buying intention: an analysis for a PDO product. British Food Journal, 108(8), 646-662. doi: doi:10.1108/00070700610682337

García-Fernández, J., Gálvez-Ruíz, P., Fernández-Gavira, J., Vélez-Colón, L., Pitts, B., \& Bernal-García, A. (2018). The effects of service convenience and perceived quality on perceived value, satisfaction and loyalty in low-cost fitness centers. Sport Management Review, 21(3), 250-262. doi: 10.1016/j.smr.2017.07.003

Gursoy, D., Chen, J. S., \& Chi, C. G. (2014). Theoretical examination of destination loyalty formation. International Journal of Contemporary Hospitality Management, 26(5), 809-827. doi: doi:10.1108/IJCHM-12-2013-0539

Ha, J., \& Jang, S. (2010). Effects of service quality and food quality: The moderating role of atmospherics in an ethnic restaurant segment. International Journal of Hospitality Management, 29(3), 520-529. doi: https://doi.org/10.1016/j.ijhm.2009.12.005

Hair, J. E., Hult, G. T., Ringle, C. M., \& Sarstedt, M. (2017). A Primer on Partial Least Squares Structural Equation Modeling (PLS-SEM) (2 ed.). Thousand Oaks: Sage.

Hair, J. F., Black, W. C., Babin, B. J., \& Anderson, R. E. (2010). Multivariate data analysis: A global perspective (7th ed.). Upper Saddle River: Pearson Education. 
Han, H., \& Hyun, S. S. (2017). Impact of hotel-restaurant image and quality of physical-environment, service, and food on satisfaction and intention. International Journal of Hospitality Management, 63, 82-92. doi: https://doi.org/10.1016/j.ijhm.2017.03.006

Harris, L. C., \& Goode, M. M. (2004). The four levels of loyalty and the pivotal role of trust: A study of online service dynamics. Journal of Retailing, 80(2), 139.

Henseler, J., Ringle, C. M., \& Sarstedt, M. (2015). A new criterion for assessing discriminant validity in variance-based structural equation modeling. Journal of the Academy of Marketing Science, 43(1), 115-135. doi: 10.1007/s11747-014-0403-8

Jeon, M. M., \& Jeong, M. (2017). Customers' perceived website service quality and its effects on eloyalty. International Journal of Contemporary Hospitality Management, 29(1), 438-457. doi: 10.1108/IJCHM-02-2015-0054

Kedah, Z., Ismail, Y., Haque, A., \& Ahmed, S. (2015). Key Success Factors of Online Food Ordering Services: An Empirical Study. Malaysian Management Review, 50(2), 19-36.

Kim, H., Woo, E., Uysal, M., \& Kwon, N. (2018). The effects of corporate social responsibility (CSR) on employee well-being in the hospitality industry. International Journal of Contemporary Hospitality Management, 30(3), 1584-1600. doi: doi:10.1108/IJCHM-03-2016-0166

Kim, J., Jin, B., \& Swinney, J. L. (2009). The role of etail quality, e-satisfaction and e-trust in online loyalty development process. Journal of Retailing and Consumer Services, 16(4), 239-247. doi: https://doi.org/10.1016/j.jretconser.2008.11.019

Kimes, S. E. (2011). Customer perceptions of electronic food ordering. Cornell Hospitality Report, 11(10), 6-15.

Liu, W.-K., Lee, Y.-S., \& Hung, L.-M. (2017). The interrelationships among service quality, customer satisfaction, and customer loyalty: Examination of the fast-food industry. Journal of Foodservice Business Research, 20(2), 146-162. doi: 10.1080/15378020.2016.1201644

Mattila, A. S. (2001). Emotional bonding and restaurant loyalty. The Cornell Hotel and Restaurant Administration Quarterly, 42(6), 73-79. doi: 10.1016/\$0010-8804(01)81012-0

Mihajlović, N. (2017). The Analysis of Serbian Customers Satisfaction with e-services Quality Dimensions of Lodging e-intermediaries. The European Journal of Applied Economics, 14(1), 48. doi: $10.5937 /$ ejae14-13242

Namkung, Y., \& Jang, S. (2007). Does Food Quality Really Matter in Restaurants? Its Impact On Customer Satisfaction and Behavioral Intentions. Journal of Hospitality \& Tourism Research, 31(3), 387-409. doi: 10.1177/1096348007299924

Ng, S.-R., Wong, S.-Y., \& Chong, L. (2017). Outsourcing to Online Food Delivery Services: Perspective of F\&B Business Owners. Journal of Internet Banking and Commerce, 22(2), 1-13.

Nitzl, C., Roldan, J. L., \& Cepeda, G. (2016). Mediation analysis in partial least squares path modeling: Helping researchers discuss more sophisticated models. Industrial Management \& Data Systems, 116(9), 1849-1864. doi: doi:10.1108/IMDS-07-2015-0302

Oliver, R. L. (1999). Whence consumer loyalty? Journal of Marketing, 63, 33-44. doi: 10.2307/1252099

Parasuraman, A., Zeithaml, V. A., \& Malhotra, A. (2005). E-S-QUAL:A Multiple-Item Scale for Assessing Electronic Service Quality. Journal of Service Research, 7(3), 213-233. doi: $10.1177 / 1094670504271156$

Pee, L., Jiang, J., \& Klein, G. (2018). E-store loyalty: Longitudinal comparison of website usefulness and satisfaction. International Journal of Market Research, January, 12, 1-17. doi: $10.1177 / 1470785317752045$

Reichheld, F. F., Markey, R. G., \& Hopton, C. (2000). The loyalty effect - the relationship between loyalty and profits. European Business Journal, 12(3), 134.

Ryu, K., \& Han, H. (2009). Influence of the Quality of Food, Service, and Physical Environment on Customer Satisfaction and Behavioral Intention in Quick-Casual Restaurants: Moderating Role of Perceived Price. Journal of Hospitality \& Tourism Research, 34(3), 310-329. doi: $10.1177 / 1096348009350624$ 
Sirgy, M. J., Efraty, D., Siegel, P., \& Lee, D.-J. (2001). A New Measure of Quality of Work Life (QWL) Based on Need Satisfaction and Spillover Theories. Social Indicators Research, 55(3), 241-302 doi: 10.1023/A:1010986923468

Srinivasan, S. S., Anderson, R., \& Ponnavolu, K. (2002). Customer loyalty in e-commerce: an exploration of its antecedents and consequences. Journal of Retailing, 78(1), 41-50. doi: 10.1016/S00224359(01)00065-3

Statista. (2018). Food Delivery Worldwide Retrieved January 20th, 2018 https://www.statista.com/outlook/374/100/food-delivery/worldwide

Sthapit, E., \& Björk, P. (2017). Activity participation home and away - examining the spillover theory among families on holiday. Anatolia, 28(2), 209-223. doi: 10.1080/13032917.2017.1311272

Suhartanto, D., Brien, A., Sumarjan, N., \& Wibisono, N. (2018). Examining attraction loyalty formation in creative tourism. International Journal of Quality and Service Sciences, 10(2), 163-175.

Suhartanto, D., Chen, B. T., Mohi, Z., \& Sosianika, A. (2018). Exploring loyalty to specialty foods among tourists and residents. British Food Journal, 120(5), 1120-1131. doi: doi:10.1108/BFJ-09-20170485

Sulek, J. M., \& Hensley, R. L. (2004). The Relative Importance of Food, Atmosphere, and Fairness of Wait: The Case of a Full-service Restaurant. Cornell Hotel and Restaurant Administration Quarterly, 45(3), 235-247. doi: 10.1177/0010880404265345

Tenenhaus, M., Vinzi, V. E., Chatelin, Y.-M., \& Lauro, C. (2005). PLS path modeling. Computational Statistics \& Data Analysis, 48(1), 159-205. doi: https://doi.org/10.1016/j.csda.2004.03.005

Wirtz, J., \& Lovelock, C. (2016). Services Marketing - People, Technology, Strategy (8th ed.). US: World Scientific Publishing.

Yeo, V. C. S., Goh, S.-K., \& Rezaei, S. (2017). Consumer experiences, attitude and behavioural intention toward online food delivery (OFD) services. Journal of Retailing and Consumer Services, 35, 150-162. doi: https://doi.org/10.1016/j.jretconser.2016.12.013

Zeithaml, V. A., Parasuraman, A., \& Malhotra, A. (2002). Service quality delivery through web sites: A critical review of extant knowledge. Journal of the Academy of Marketing Science, 30(4), 362. doi: 10.1177/009207002236911

Zikmund, W. G., Babin, B. J., Carr, J. C., \& Griffin, M. (2013). Business Research Methods (9th ed.). Mason, $\mathrm{OH}$ : South-Western, Chengage. 
Table 1 E-service quality item and sources

\begin{tabular}{|c|c|c|}
\hline \# & Item & Source \\
\hline 1 & In the web, I can find easily what I need & \multirow{12}{*}{$\begin{array}{l}\text { (Caruana \& Ewing, } \\
\text { 2010; Jeon \& Jeong, } \\
\text { 2017; Kedah et al., 2015; } \\
\text { Kim et al., 2009; } \\
\text { Parasuraman et al., 2005; } \\
\text { Srinivasan et al., 2002) }\end{array}$} \\
\hline 2 & The web makes it easy to get anything & \\
\hline 3 & The web is uncomplicated to operate & \\
\hline 4 & Whenever I need the web always available & \\
\hline 5 & The web launches straight away & \\
\hline 6 & The delivering order is as promised & \\
\hline 7 & The items ordered is sent out promptly & \\
\hline 8 & The web offering is honest & \\
\hline 9 & The web accurately inform the delivery promise & \\
\hline 10 & The web keeps my shopping behaviour information & \\
\hline 11 & My personal information is not shared by the web & \\
\hline 12 & My payment ID is safe with the web & \\
\hline
\end{tabular}

Table 2. Demographic characteristics of the respondents

\begin{tabular}{|l|l|l|l|}
\hline Variable & Description & Frequency & $\%$ \\
\hline \multirow{4}{*}{ Gender } & Male & 116 & 28,6 \\
\cline { 2 - 4 } & Female & 289 & 71,4 \\
\hline \multirow{4}{*}{ Age } & $17-20$ & 116 & 28,6 \\
\cline { 2 - 4 } & $21-30$ & 271 & 66,9 \\
\cline { 2 - 4 } & $31-40$ & 11 & 2,7 \\
\cline { 2 - 4 } Occupation & Over 40 & 7 & 1,7 \\
\hline & Student & 10 & 2.5 \\
\cline { 2 - 4 } & $\begin{array}{l}\text { University } \\
\text { student }\end{array}$ & 306 & 76 \\
\hline
\end{tabular}




\begin{tabular}{|l|l|l|l|}
\hline \multirow{5}{*}{$\begin{array}{l}\text { Average purchasing } \\
\text { frequency }\end{array}$} & Worker & 82 & 20 \\
\cline { 2 - 4 } & Housewife & 2 & 0.5 \\
\cline { 2 - 4 } & Others & 5 & 1.2 \\
\hline \multirow{4}{*}{ Last order food delivery } & $<2 /$ month & 236 & 58 \\
\cline { 2 - 4 } & $3-5 /$ month & 134 & 33 \\
\cline { 2 - 4 } & $>5 /$ month & 35 & 8.6 \\
\hline & GoFood & 337 & 83 \\
\cline { 2 - 4 } & GrabFood & 13 & 3.2 \\
\cline { 2 - 4 } & Restaurant Web & 55 & 14 \\
\hline
\end{tabular}

Table3. Loading of the item measurement model, $C R$, and AVE

\begin{tabular}{|l|l|l|l|l|}
\hline & Loading & Cronbach & CR & AVE \\
\hline E-Service quality & & 0.941 & 0.949 & 0.607 \\
\hline -In the web, I can find easily what I need & 0.735 & & & \\
\hline -The web makes it easy to get anything & 0.737 & & & \\
\hline -The web is uncomplicated to operate & 0.784 & & & \\
\hline -Whenever I need the web always available & 0.737 & & & \\
\hline -The web launches straight away & 0.747 & & & \\
\hline -The delivering order is as promised & 0.790 & & & \\
\hline -The items ordered is send out promptly & 0.831 & & & \\
\hline -The web offering is honest & 0.768 & & & \\
\hline -The web accurately inform the delivery promise & 0.838 & & & \\
\hline -The web keeps my shopping behaviour information & 0.811 & & & \\
\hline -My personal information does not shared by the web & 0.803 & & & \\
\hline -The payment ID is safe with the web & 0.759 & & & \\
\hline Food quality & & 0.771 & 0.853 & 0.592 \\
\hline -Presentation & 0.733 & & & \\
\hline -Variety & 0.791 & & & \\
\hline -Taste & 0.828 & & & \\
\hline -Healthy option & 0.721 & & & \\
\hline Perceived value & & 0.841 & 0.904 & 0.758 \\
\hline -Offer reasonable price & 0.854 & & & \\
\hline -Cost benefit ratio & 0.873 & & & \\
\hline -Overall convenience of the web & 0.884 & & & \\
\hline Satisfaction & & 0.900 & 0.952 & 0.909 \\
\hline -Dissatisfied to satisfied & 0.950 & & & \\
\hline -Terrible to pleased & 0.956 & & & \\
\hline Loyalty & & 0.697 & 0.803 & 0.509 \\
\hline -Continue to purchase & 0.691 & & & \\
\hline -Intention to recommend & 0.837 & & & \\
\hline -Intention to say positive thing & 0.704 & & & \\
\hline -Continue purchase even the price increase & 0.602 & & & \\
\hline
\end{tabular}


Table 4. Structural estimates

\begin{tabular}{|l|r|r|r|l|l|r|}
\hline \multirow{2}{*}{ Path } & \multicolumn{2}{|c|}{ Direct } & \multicolumn{2}{c|}{ Indirect } & \multicolumn{2}{c|}{ Total Effect } \\
\cline { 2 - 8 } & $\beta$ & $\mathrm{t}-\mathrm{value}$ & $\beta$ & $\mathrm{t}$-value & $\beta$ & $\mathrm{t}$-value \\
\hline E-Service Quality => Loyalty & 0.031 & 0.545 & 0.428 & $8.511 * *$ & 0.459 & $8.010^{* *}$ \\
\hline Food Quality => Loyalty & 0.256 & $4.146^{* *}$ & 0.179 & $5.102 * *$ & 0.435 & $7.428^{* *}$ \\
\hline E-Service Quality => Food Quality & 0.609 & $11.714^{* *}$ & - & - & 0.609 & $11.714^{* *}$ \\
\hline E-Service Quality => Perceived Value & 0.335 & $5.070^{* *}$ & 0.281 & $7.547 * *$ & 0.616 & $10.522^{* *}$ \\
\hline E-Service Quality => Satisfaction & 0.304 & $4.449^{* *}$ & 0.325 & $6.283 * *$ & 0.629 & $12.156^{* *}$ \\
\hline Food Quality => Perceived Value & 0.462 & $8.220^{* *}$ & - & - & 0.462 & $8.220^{* *}$ \\
\hline Food Quality => Satisfaction & 0.230 & $4.088^{* *}$ & 0.139 & $4.693 * *$ & 0.369 & $6.275^{* *}$ \\
\hline Perceived Value => Satisfaction & 0.300 & $5.131^{* *}$ & - & - & 0.300 & $5.131^{* *}$ \\
\hline Perceived Value => Loyalty & 0.197 & $3.007 * *$ & 0.072 & $2.727 * *$ & 0.269 & $4.729 * *$ \\
\hline Satisfaction => Loyalty & 0.240 & $3.700^{* *}$ & - & - & 0.240 & $3.700^{* *}$ \\
\hline
\end{tabular}

$* *$ significant at $\mathrm{p}<0.01$ 